\title{
LAS PRIMERAS TEORÍAS SOBRE EL SENADO EN ESPAÑA
}

\author{
IGNACIO FERNÁNDEZ SARASOLA \\ Profesor Titular de Derecho Constitucional \\ Universidad de Oviedo
}

SUMARIO

I. La temprana teorización sobre el Senado.

II. El debate sobre el Senado antes de las Cortes de Cádiz.

III. El Senado oculto por el modelo revolucionario.

"Alguno, oyéndome discurrir sobre estos principios, me reconvino: "¿Conque usted quiere hacernos ingleses? - Si usted, le respondi, conoce bien la constitución de Inglaterra; si ha leido lo que de ella han escrito Montesquieu, De-Lolme y Blackstone; si sabe que el sabio republicano Adams dice de ella que es en la teórica la más estupenda fábrica de la bumana invención, asi por el establecimiento de su balanza como por los medios de evitar su alteración... y que ni la invención de las lenguas ni el arte de la navegación y construcción de naves hacen más honor al entendimiento bumano; si ha observado los grandes bienes que este ilustre y poderoso pueblo debe a su constitución, y si ha penetrado las grandes analogias que bay entre ella y la antigua constitución española, y en fin, si usted reflexiona que no sólo puede conformarse con ella, sino que cualquiera imperfección parcial que se advierta en la constitución inglesa, y cualquiera repugnancia que tenga con la nuestra, se pueden evitar en una buena reforma constitucional, ciertamente que la reconvención de usted será tan poco digna de su boca como de mi oído"."

Gaspar Melchor de Jovellanos, Palabras vertidas en la Comisión de Cortes, recogidas en Memoria en defensa de la Junta Central, 1811

UNED. Teoría y Realidad Constitucional, núm. 17, 2006, pp. 169-193. 
"Y ¿cuál podía ser el apoyo de la Cámara privilegiada? ¿Qué leyes nacionales, qué costumbres y prácticas antiguas, qué tradiciones y recuerdos célebres, populares, dignos de veneración, aprecio y gratitud, le servian de fundamento?.

Agustín Argüelles, Examen bistórico de la reforma constitucional de España (1834)

\section{LA TEMPRANA TEORIZACIÓN SOBRE EL SENADO}

Es de sobra conocido que el bicameralismo nace en España en 1834, con el Estatuto Real ${ }^{1}$, coincidiendo con el abandono del modelo revolucionario doceañista y su sustitución por el modelo británico de Monarquía Constitucional, que adaptaba nuestro país al "espíritu del siglo" al que se refería Martínez de la $\mathrm{Rosa}^{2}$. Precisamente este autor había comparado el unicameralismo con un ariete, "excelente arma para demoler, instrumento malisimo para edificar" ${ }^{3} \mathrm{y}$ consideraba imprescindible que todo gobierno contase con una Cámara Alta, lo que le llevó a diseñar el Estamento de los Próceres del Estatuto Real.

Ahora bien, la historia del constitucionalismo no se circunscribe al estudio de las Constituciones, sino también de la doctrina, de los ensayos constitucionales, de los proyectos truncados ${ }^{4}$. Si se adopta esta perspectiva, la historia del Senado - no ya como realidad normativa ni institucional, pero sí como idease puede retrotraer unos años, a comienzos del XIX, cuando surgieron las primeras teorizaciones sobre la Cámara Alta, e incluso los primeros intentos para convertirla en realidad. Cambiando, así, de lente constitucional, casi podría aventurarse que el Estatuto Real no representa un comienzo en la historia del Senado, sino más bien una primera culminación. Y es que en 1834 se lograría plasmar normativamente una idea que ya se había ido gestando desde 1809,

1 Aunque algunos estudios atribuyen este mérito al Estatuto de Bayona. Vid., por ejemplo: Antonio Torres del Moral, Constitucionalismo bistórico español, Átomo Ediciones, Madrid, 1986, págs. 30 y ss. Francisco Fernández Segado, Las Constituciones históricas españolas, ICAI, Madrid, 1982, págs. 61 y ss. Emilo Attard, El constitucionalismo español: 1808-1978, Valencia, 1988, pág. 51. Sin embargo, esta apreciación no parece correcta. El Senado que contiene el Estatuto de 1808 nada tiene que ver con una Cámara Alta: se trata de un órgano característico del constitucionalismo napoleónico encargado de controlar la acción de los agentes ejecutivos, y que asumía también cometidos de garantía constitucional (anulación de actos inconstitucionales de las juntas electorales) y de suspensión de dicha norma. Ya lo vio con claridad en su día el Conde de Toreno, Historia del levantamiento, guerra y revolución de España, B.A.E., vol. LXIV, Atlas, Madrid, 1953, pág. 87.

2 Francisco Martínez de la Rosa, El Espiritu del Siglo, en Obras de Francisco Martínez de la Rosa, B.A.E., núm. 152 (V), Atlas, Madrid, 1960.

3 Ibídem, pág. 80.

4 Sobre los proyectos constitucionales como fuente esencial para la historia constitucional vid. Ignacio Fernández Sarasola, Proyectos constitucionales en España (1786-1824), C.E.P.C., Madrid, 2004. En general, sobre la metodología de la historia constitucional, resulta imprescindible ver Joaquín Varela Suanzes, "Constitutional History: some methodological questions", European Journal of Political Theory, 5(4) 2006 (en prensa). 
pero que había fracasado en su día por el peso que tuvo el modelo francés de 1791 entre el primer liberalismo dominante.

Pero si se pretende buscar con tino la primera historia de la Cámara Alta en España, es preciso también huir del nominalismo, porque no toda institución diseñada al amparo del nomen iuris de "Senado" equivalía a una Cámara Alta. El ejemplo más palmario es el Senado que establecía el Estatuto de Bayona de 1808 y que no era sino un órgano característico del constitucionalismo napoleónico, tomado de la Constitución francesa del año VIII según la reforma operada por el Senado-Consulto del año XII (1804) ${ }^{5}$. Pero no es el único ejemplo. En 1805 se publicaba en Valencia un escrito político anónimo, titulado Teoría de una Constitución política para España, que contenía un interesante y original proyecto constitucional en cuyo organigrama figuraba un Senado ${ }^{6}$. Sin embargo, tampoco en este caso se trataba de una Cámara Alta, sino que de un Consejo de Estado; diseñado como órgano consultivo del Rey, no participaba en el procedimiento legislativo, salvo para ser consultado sobre la idoneidad de la sanción regia, ni asumía los cometidos jurisdiccionales de los Senados en los procesos de impeachment.

En este artículo analizaré los primeros intentos de construir en España una Cámara Alta, a fin de mostrar cómo se encuentran ya presentes en las fases iniciales de nuestro constitucionalismo. Es más, el debate sobre el Senado dividió primero a liberales y realistas, y después tuvo un papel determinante en la fractura del propio liberalismo, llegando a adquirir un carácter simbólico, que convirtió al unicameralismo en sinónimo de revolución, y al bicameralismo de reacción.

Inicialmente, la preocupación cardinal que aglutinó a todo el movimiento constitucionalista fue la de convocar Cortes, prácticamente abandonadas desde las que reuniera en 1539 en Toledo Carlos V. Sólo cuando las primeras Cortes modernas, presuntamente renacidas de las cenizas, se columbraron como una realidad posible (en 1808) se planteó el problema de su organización, y fue entonces cuando la Constitución francesa del año III y, sobre todo el modelo británico, ejercieron una poderosa influencia entre quienes empezaban a considerar la necesidad de una Cámara Alta. Pero todavía el conocimiento del sistema de gobierno de Albión resultaba muy superficial, por lo que la idea de Senado se trató de adaptar a instituciones nacionales poco o nada relacionadas con él. La Cámara Alta era más bien una "sensación", una idea vaga que evocaba equilibrio entre democracia y Monarquía; y esta armonía trató de llenarse en España con émulos de antiguas instituciones castellanas, catalanas y aragonesas. No sólo las lecturas extranjeras, sino también la influencia directa de británicos muy allegados a España,

5 Véase la nota 1.

6 Teoría de una Constitución política para España, por un español, Venancio Oliveres, Valencia, 1822, firmado por R. d. 1. SS. G. P. el 29 de octubre de 1805. Lamentablemente encontré este proyecto apenas dos años después de concluir mi libro sobre Proyectos constitucionales en España (1786-1824). 
como Lord Holland o John Allen, iluminaría el significado del bicameralismo británico, que después se reforzaría con el elogio que el pensamiento posrevolucionario europeo haría de él (desde Constant a Chateaubriand, pasando por Guizot y Madame de Staël). A partir de entonces la Cámara Alta sobre todo de componente aristocrático- se convertirá en la enseña del constitucionalismo menos revolucionario representado, en un primer momento, por el reformismo heredero de la Ilustración, y más tarde el liberalismo moderado.

Así las cosas, parece necesario empezar a replantearse la repercusión que el segundo exilio liberal (1824-1833) tuvo para nuestra historia ${ }^{7}$. No puede negarse que tras la caída del Trienio Constitucional los liberales que sufrieron el exilio en Francia e Inglaterra asimilaron el modelo británico (también existente en Francia desde 1814), pero ya mucho antes uno de sus elementos capitales, el bicameralismo, fue defendido por grupos principalmente anglófilos.

\section{EL DEBATE SOBRE EL SENADO ANTES DE LAS CORTES DE CÁDIZ}

\section{II.1. LA FASE DE «INDIFERENCIA» HACIA LA ORGANIZACIÓN PARLAMENTARIA}

A finales del siglo XVIII comienzan a surgir en España las primeras voces que claman por la convocatoria de Cortes verdaderamente representativas. Coincide la etapa con una fase de crítica política que, aunque ya presente con Carlos III a través de algunos escritos de El Censor ${ }^{8}$, realmente eclosiona cuando Carlos IV - carente de la vocación ilustrada de su antecesor- ocupa el trono. La irrupción de la literatura política extranjera (que había alentado el propio Carlos III y a la que sólo se puso freno por Floridablanca tras el estallido de la Revolución Francesa ${ }^{9}$ ) permitió conocer otras realidades políticas: una Francia convulsa, unos Estados Unidos tan distantes política como geográficamente, y una Gran Bretaña que irradiaba estabilidad y un equilibrio entre libertad y orden. En este último país hallará el bicameralismo español su referente y principal fuente de inspiración.

7 Sobre la indudable importancia de este cambio operado en el Trienio vid. Joaquín Varela Suanzes, "El pensamiento constitucional español en el exilio: el abandono del modelo doceañista (1823-1833)», Revista de Estudios Políticos, núm. 88, 1995, págs. 63 y ss. El profesor Varela no deja de advertir, sin embargo, que el cambio no fue brusco en el segundo exilio, sino que ya se atisbaba en el primer exilio, e incluso al final del período gaditano.

8 Vid. por ejemplo $E l$ Censor, Discurso XXXI, (6 de septiembre de 1781), pág. 477 o $E l$ Censor, Discurso LXV (18 de marzo de 1784), págs. 289-306. Este periódico fue editado por Cañuelo y Pereyra, el último de los cuales sería diputado en la Junta de Bayona.

9 Vid. Novísima Recopilación de las Leyes de España, Tomo IV, Libro VIII, Título XVII, Ley V, pág. 151 y Título XVII, Ley XI, donde se prohibía "la introducción y curso en estos mis Reinos y Señoríos de cualesquiera papeles sediciosos y contrarios a la fidelidad y a la tranquilidad pública y al bien y felicidad de mis vasallos» (pág. 158). 
Inglaterra se veía a través de los ojos de Montesquieu, De Lolme, y Blackstone, que retrataban un cuadro casi idílico, en el que un Parlamento bicameral contrarrestaba el poder regio logrando una balanza constitucional que actuaba como un perfecto mecanismo de relojería ${ }^{10}$. Norteamérica, aunque menos conocida, también había difundido al mundo su sistema constitucional, presidencialista, republicano y federal, poco exportable a otras realidades políticas, como la española, pero ejemplo de la racionalidad ilustrada ${ }^{11}$. Finalmente, Francia empezaba a mostrar desde 1789, y sobre todo a partir de 1791, el peso de la representación popular, y las lecturas de Rousseau, Mably o Sieyès iban complementando y sustituyendo paulatinamente a Voltaire, D'Alembert o Fénelon en los anaqueles de las bibliotecas privadas. Experiencias comparadas muy distintas, es cierto, pero con un denominador común del que se hizo la máxima abstracción: no se trataba de gobiernos absolutos, sino limitados por la presencia de un Parlamento.

El sistema de gobierno de España, con un Rey absoluto apenas frenado por sus Consejos, salía perjudicado de la comparación con estos modelos. Así lo retrató con claridad León de Arroyal en su célebre Pan y $\operatorname{Toros}^{12}$ y, años después, con sus no menos incisivas Cartas al Conde de Lerena ${ }^{13}$. La necesidad de que el pueblo obtuviese algún tipo de representación respondía no sólo a una necesidad política — refrenar el poder regio_-, sino que también era el lógico resultado de la filosofía iusracionalista que había circulado por España desde Carlos III, desplazando progresivamente al iusnaturalismo escolástico ${ }^{14}$. En efecto, cuando en 1786 Manuel de Aguirre proponía la formación de un embrionario órgano representativo, lo hacía como derivación natural de una teoría del pacto social lockeana ${ }^{15}$.

10 Véase el sugerente libro de Otto Mayr, La bilancia e l'orologio. Libertà e autorità nel pensiero politico dell'Europa Moderna, Il Mulino, Bologna, 1988.

11 En España tuvo cierta difusión el libro de John Adams, A defence of the Constitutions of government of the United Status of America, C. Dilly, London, 1787.

12 Decía Arroyal de los ingleses y franceses que "idólatras de su libertad, tienen por pesado un solo eslabón de la servidumbre", mientras que los españoles, "arrastrando las cadenas de la esclavitud, no conocen siquiera el ídolo de la libertad". León de Arroyal, Pan y toros (Oración apologética en defensa del estado floreciente de España) (hacia 1792, publicado en 1812), en Antonio Elorza (edit.), Pan y Toros y otros papeles sediciosos de fines del siglo XVIII, Ayuso, Madrid, 1971, pág. 31.

13 Redactadas entre 1786 y 1790, las Cartas económico-politicas al Conde de Lerena suponían una dura crítica a la política absolutista de Carlos III. Arroyal firmaría un segundo grupo de Cartas dirigidas a Francisco Saavedra (1792-1795) donde llegó a incluir un proyecto constitucional.

14 Así se manifiesta en la progresiva creación desde 1774 de Cátedras de Derecho Natural y de Gentes, aunque bien es cierto que de forma bastante limitada. Cfr. Antonio Álvarez de Morales, Estudios de historia de la Universidad española, Pegaso, Madrid, 1993, págs. 141 y 153. Cfr. Antonio Jara Andreu, Derecho Natural y conflictos ideológicos en la Universidad española (17501850), Instituto de Estudios Administrativos, Madrid, 1977, pág. 89.

15 Cfr. Manuel de Aguirre, Discurso sobre legislación firmado con el seudónimo de «El Militar Ingenuo" y publicado en el Correo de Madrid, tomo II, núm. 107 (31 de octubre de 1787), núm. 108 (3 de noviembre de 1787) y núm. 109 (7 de noviembre de 1787). El texto constitucional lo he reproducido en Ignacio Fernández Sarasola, Proyectos constitucionales en España (1786-1824), op. cit., págs. 9 y ss. 
Pero precisamente Manuel de Aguirre ejemplifica bien una circunstancia común al siglo XVIII español: aunque se proclamaba doctrinalmente la necesidad de Cortes, todavía no se planteaban los pormenores de su organización y, en concreto, no se discutía sobre su carácter unicameral o bicameral ${ }^{16}$. El objetivo eran las Cortes, y el problema de su estructura se ignoraba. Así lo hizo también León de Arroyal, cuando elaboró una "idea de Constitución" en la que se recogían unas Cortes de cuya estructura nada se dice ${ }^{17}$. Las referencias al bicameralismo venían de obras como la del Duque de Almodóvar, que se limitaban a describir el gobierno de Inglaterra siguiendo muy de cerca a autores como Blackstone o De Lolme ${ }^{18}$.

El estallido de la Guerra de la Independencia incrementó las solicitudes de formar Cortes. Vacante el trono, se consideraba que el pueblo había recobrado su soberanía (concepción neoescolástica) y que debía tomar las riendas del país, organizando unas Cortes encargadas, entre otras cosas, de elegir un Consejo de Regencia ${ }^{19}$. Ahora bien, estos primeros planteamientos eran deudores del siglo XVIII; el problema bicameral todavía no se planteaba, porque el objetivo era abstracto y ambiguo: convocar un Parlamento para gestionar una crisis.

El choque entre las instituciones del Antiguo Régimen (como el Consejo de Castilla) y las nuevas fuerzas políticas surgidas de la Guerra (como las Juntas Provinciales) se manifestaba ante todo en el modo de elegir a las Cortes y de determinar su composición, pero todavía no se discrepaba en torno al bicameralismo, sobre el que existía un elocuente silencio. Así, el Consejo de Castilla, arraigado en el Antiguo Régimen, trataba de reunir una Asamblea de acuerdo con la tradición nacional, es decir, llamando sólo a las ciudades con voto en Cortes, y con el objetivo reducido de que designasen una Regencia conforme a

16 Sin embargo, se planteaba en ocasiones la composición del Parlamento. Así, Victorián de Villava, por ejemplo, indicaba que en el Parlamento o "Consejo Supremo de la Nación" tenía que haber un tercio de eclesiásticos. Vid. Victorián de Villava, Apuntes para una reforma de España, sin trastorno del Gobierno Monárquico ni la Religión (1797), en Ricardo Levene (editor), Vida y escritos de Victorián de Villaba, Peuser, Buenos Aires, 1945, págs. LXXXVII-LXXXVIII.

17 León de Arroyal, Cartas económico-políticas, 2. ${ }^{a}$ parte. Manuscrito perteneciente al Instituto Feijoo de Estudios del Siglo xviII. Carta Quinta (San Clemente, 24 de octubre de 1794), Carta Sexta (San Clemente, 1 de noviembre de 1794) y Carta Séptima (San Clemente, 3 de marzo de 1795). Lo he reproducido a partir del citado manuscrito en: Ignacio Fernández Sarasola, Proyectos constitucionales en España (1786-1824), op. cit., págs. 20 y ss.

18 Cfr. Duque de Almodóvar, Constitución de Inglaterra (1785), edición y estudio preliminar de Jesús Vallejo, C.E.P.C., Madrid, 2000, en especial Capítulo IV, págs. 37 y ss, donde se analizaba la composición aristocrática de la Cámara de los Lores y sus funciones destinadas a procurar el equilibrio constitucional entre el Rey y el Pueblo. A pesar de carácter descriptivo del texto, es cierto que en él ya se ve una cierta tendencia favorable al bicameralismo: por una parte, la Cámara de los Lores se analizaba antes que la Cámara de los Comunes, y se insistía en la superioridad de la primera (pág. 38).

19 Vid. por ejemplo el texto de Juan Pérez Villamil, Carta sobre el modo de establecer el Consejo de Regencia del Reino con arreglo a nuestra Constitución, Imprenta de Josef de Orga, Valencia, 1808, pág. 23. La misma idea la propuso Jovellanos en su Dictamen sobre la institución del gobierno interino (7 de octubre de 1808), en Jovellanos, Memoria en defensa de la Junta Central (1811), Junta General del Principado de Asturias, Oviedo, 1992, vol. II, págs. 51 y ss. 
las Partidas ${ }^{20}$. Algunas Juntas Provinciales que habían surgido como poderes revolucionarios aspiraban, por el contrario, a formar unas Cortes con una composición muy distinta a la tradicional, puesto que sus miembros serían designados por las propias Juntas ${ }^{21}$. Pero tampoco las Provinciales hicieron referencia alguna al bicameralismo.

\section{II.2. El DEBATE "OFICIOSO" SOBRE EL BICAMERALISMO}

Como es bien sabido, las Juntas Provinciales no reunieron finalmente Cortes, sino un órgano ejecutivo, la Junta Central. Sólo a partir de entonces comenzaría a plantearse el problema del bicameralismo, y lo haría con creciente intensidad. Jovellanos ya había propuesto en el seno de la Junta que se reuniesen Cortes $^{22}$; proposición que reactivó meses más tarde Calvo de Rozas ${ }^{23}$, aunque en ambos casos todavía el aspecto organizativo se silenciaba. El 22 de mayo de 1809, la Junta Central se decidía a expedir un Decreto de convocatoria de Cortes que pasaría a la historia como el llamamiento de la denominada "Consulta al país". Y es que en el Decreto se solicitaba a particulares e instituciones (tanto del Antiguo Régimen, como surgidas de la revolución, como eran las Juntas Provinciales) que enviasen a la Central sus reflexiones acerca de las reformas que debían introducirse en las Leyes Fundamentales.

El resultado de esta consulta fue la recepción de más de un centenar de informes que, por supuesto, trataban el problema de las Cortes. Los documentos constituyen, pues, un fiel estado de la opinión pública (que nunca hasta entonces había tenido tan sobresaliente papel) sobre cómo organizar el sistema político español ${ }^{24}$. Precisamente la distancia que separaba a unos y otros en este punto permite clasificarlos en informes liberales, o informes que responden a una concepción reformista ${ }^{25}$.

20 Véase el dictamen expedido por los fiscales del Consejo e incluido en el Oficio que éste remitió a la Junta Central el 30 de septiembre de 1808 en Manuel Fernández Martín, Derecho parlamentario español, Publicaciones del Congreso de los Diputados, Madrid, 1992, vol. I, pág. 382.

21 Vid. Ángel Martínez de Velasco, La formación de la Junta Central, Ediciones Universidad de Navarra, Pamplona, 1972, págs. 104 y ss.

22 Dictamen sobre la institución del gobierno interino (7 de octubre de 1808), op. cit., págs. 51 y ss.

23 Proposición de Calvo de Rozas sobre convocatoria de Cortes (15 de abril de 1809), en Manuel Fernández Martín, Derecho parlamentario español, op. cit., págs. 436-438.

24 Sólo dos autores se han ocupado de recoger de los Archivos Históricos los informes: Miguel Artola y Federico Suárez. El primero reproduce parcialmente 68 de los mismos en su volúmen segundo de la obra Los orígenes de la España contemporánea, Instituto de Estudios Políticos, Madrid, 1976. El profesor Federico Suárez, por su parte, emprendió la difícil tarea de agrupar estos documentos de forma íntegra, divididos por regiones, si bien tan solo ha publicado, en tres volúmenes, los referentes a Baleares, Andalucía, Extremadura, Valencia y Aragón. Federico Suárez, Cortes de Cádiz. Informes Oficiales sobre Cortes, EUNSA, Pamplona, vol. I (1967), vol. II (1968) y vol. III (1974).

25 Vid. Ignacio Fernández Sarasola, Poder y libertad. Los orígenes de la responsabilidad del Ejecutivo en España (1808-1823), C.E.P.C., Madrid, 2001, págs. 239 y ss. 
Los primeros partían de forma casi unánime de una idea unicameral. En virtud del principio de igualdad y de soberanía nacional (o popular, según los casos ${ }^{26}$ se pretendía organizar las Cortes en una sola Cámara con representación indiferenciada de los ciudadanos. En su mayor parte, estos escritos diseñaban un sistema de predominio parlamentario, que alcanzaba a ser asambleario en algunos casos, al convertir al Rey en un órgano meramente ejecutivo, sujeto a la voluntad de un Parlamento dotado de la exclusiva dirección política del Estado ${ }^{27}$. Destaca, sin embargo, un texto remitido a la Junta Central en 1809 por Flórez Estrada, por ser el único que defiende con claridad la presencia de una Cámara Alta. Con el nombre de "Constitución para la nación española", el liberal asturiano presentó un documento articulado en el que el Parlamento o Congreso nacional soberano se estructuraba en una "Sala o Cámara Grande" y una "Sala de los respetables" (art. 38), dotando a ambas de idénticas competencias legislativas y tributarias. La "Sala de los respetables" estaría integrada por cien representantes, que debían tener más de 50 años y que serían elegidos, como los de la Cámara Grande, por las Juntas de las provincias (art. 13). A pesar de que, como he mencionado, Flórez Estrada atribuía a ambas Cámaras iguales competencias, lo cierto es que el art. 40 asignaba a la Cámara Grande una competencia de relieve, de la que carecía la Sala de Respetables: designar una comisión permanente encargada de velar por la Constitución ${ }^{28}$.

Huelga decir que el bicameralismo propuesto por Flórez Estrada nada tenía que ver con el sistema británico, sino que estaba ligado a la Constitución francesa del año III $^{29}$. Una Constitución que se había difundido por España, y que convenció incluso a algunos reticentes al constitucionalismo revolucionario

26 Junta de Badajoz, Badajoz, 12 de noviembre de 1809, en: Federico Suárez, Cortes..., op. cit., vol. III, pág. 295; Ayuntamiento de Granada, Granada, 25 de noviembre de 1809, en: Federico Suárez, Cortes..., op. cit., vol. III, pág. 194; Fernando Andrés Benito, Granada, ¿23 de noviembre? de 1809. En: Miguel Artola, Los orígenes..., op. cit., vol. II, pág. 475.

27 Informe de Antonio Panadero, 2 de febrero de 1809. En: Miguel Artola, Los orígenes de la España contemporánea, op. cit., vol. II, págs. 645-662; Informe de José de la Madre, agosto de 1809, en ibidem, págs. 388-399 y en Ignacio Fernández Sarasola, Proyectos constitucionales en España (1786-1824), op. cit., págs. 78-88.

28 El texto puede consultarse en Ignacio Fernández Sarasola, Proyectos constitucionales en España (1786-1824), op. cit., págs. 92 y ss.

29 En 1818 Flórez llegaría, sin embargo, a admitir un bicameralismo de corte británico como punto intermedio entre la Constitución del 12 y el absolutismo fernandino. En su Representación a Fernando VII, el liberal español le pedía que, aunque no admitiera el texto gaditano, al menos convocase unas "Cortes o representantes de la nación, elegidos (por abora) con arreglo a lo prevenido en las últimas, sin perjuicio de que en lo sucesivo se nombre una Cámara alta, compuesta de grandes, nobles y alto clero, elegidos temporal o perpetuamente por V. M., pero cuya institución se determine por leyes fundamentales". Álvaro Flórez Estrada, Representación hecha a S. M. C. el Señor Don Fernando VII, en defensa de las Cortes, en Obras de Álvaro Flórez Estrada, B.A.E., vol. CXIII, Atlas, Madrid, 1958, pág. 209. No era la convicción la que movía a Flórez a esta propuesta, sino el intento de que el régimen representativo pudiera subsistir de alguna manera bajo el báculo de Fernando VII.

30 Jovellanos recibió el texto de la Constitución a finales de noviembre de 1795 (Jovellanos, Diario, 26 de noviembre de 1795, en Obras completas, vol. VII, Instituto Feijoo de Estudios del Si- 
galo, como Jovellanos ${ }^{30}$. Por otra parte, la elección de los «respetables» mediante las Juntas Provinciales introducía un sistema de representación indirecta con un componente de territorialidad, muy del gusto, por cierto, de algunas Juntas, que todavía gustaban autoproclamarse "soberanas" orientando España hacia el federalismo ${ }^{31}$.

Un segundo grupo de informes se alejaba de los postulados liberales (pacto social, asambleísmo, Constitución racional-normativa, poder constituyente...) y defendía una postura que puede denominarse como "reformista". No pretendían abordar un proceso constituyente, sino enmendar las antiguas Leyes Fundamentales ${ }^{32}$, a las que conferían en algunos puntos (la Monarquía, la confesionalidad estatal...) una intangibilidad absoluta ${ }^{33}$. Los escritos reformistas apostaban por un sistema de gobierno de equilibrio constitucional, generalmente de imitación británica, con unas Cortes estamentales. Bien es cierto que estas Cortes que proponían eran unicamerales, pero la idea de balanza constitucional hizo que buscaran un émulo del Senado. Según los comentaristas del gobierno británico, la Cámara Alta actuaba como intermedio entre el Rey y el pueblo (la Cámara Baja) o, lo que es lo mismo, entre la Monarquía y la Democracia. Pues bien, los textos reformistas trataron de reproducir esta idea, sustituyendo la Cámara de los Lores por un órgano que evocase antiguas instituciones españolas, como los jueces de greuges ${ }^{34}$ o el Justicia Mayor de Aragón ${ }^{35}$.

glo XVIII —Ayuntamiento de Gijón, Oviedo, 1999, pág. 487)—. El 29 de noviembre admite que le parece una obra admirable (Diario, 29 de noviembre de 1795, en ibídem, pág. 488) y continúa su lectura en los días sucesivos (Diario, 30 de noviembre, 1 de diciembre y 2 de diciembre, en ibídem, págs. 489-490).

31 Blanco White criticó precisamente este componente "federal" (según citaba el propio Blanco) del proyecto constitucional de Flórez Estrada. El Español, núm. 9, 30 de diciembre de 1810, págs. 195-196, 198, 200-201. Vid. Ignacio Fernández Sarasola, "El pensamiento político-constitucional de Álvaro Flórez Estrada a través de la prensa", en Joaquín Varela Suanzes-Carpegna (coord.), Álvaro Flórez Estrada (1766-1853). Política, economia, sociedad, Junta General del Principado de Asturias, Oviedo, 2004, págs. 214 y ss. Sobre la tendencia de las Juntas Provinciales hacia el federalismo, véanse las palabras vertidas por los exvocales de la Junta Central ante las Cortes de Cádiz en Exposición que hacen a las Cortes Generales y Extraordinarias de la Nación española los individuos que compusieron la Junta Central Suprema Gubernativa de la misma, de su conducta en el tiempo de su administración, Imprenta del Estado Mayor General, Cádiz, 1811, pág. 11.

32 Cabildo de Segorbe, Segorbe, 8 de octubre de 1809. En: Federico Suárez, Cortes..., op. cit., vol II, págs. 152-153.; Arzobispo de Tarragona, Tarragona, 5 de noviembre de 1809, en: Miguel Artola, Los orígenes..., op. cit., vol. II,, pág. 129; Obispo de Lérida, Lérida, 17 de diciembre de 1809, en ibídem, pág. 202; Ayuntamiento de Cádiz, 30 de septiembre de 1809, en: Federico Suárez, Cortes..., op. cit., vol. III, pág. 91; Andrés Diest de la Torre, Granada, 30 de septiembre de 1809. En: Miguel Artola, Los orígenes..., op. cit., vol. II, pág. 543.

33 Cabildo de Cuenca, Cuenca, 31 de octubre de 1809. En: Miguel Artola, Los orígenes...,op. cit., vol. II, pág. 239.

34 Ramón Lázaro de Dou, Cervera, 17 y 29 de agosto de 1809. En: Miguel Artola, Los orígenes..., op. cit., vol. II, págs. 339 y 416. Este autor tenía un amplio conocimiento de las instituciones catalanas y del que hacía uso frecuente en su producción literaria.

35 Ayuntamiento de Cádiz, 30 de septiembre de 1809. En: Federico Suárez, Cortes..., op. cit., vol. III, pág. 132. Manuel Fernández Manrique, Cuenca, 4 de septiembre de 1809, en: Miguel Artola, Los orígenes..., op. cit., vol. II, pág. 621. 
La idea de crear un iudex medius ${ }^{36}$, que velara por las Leyes Fundamentales y, por tanto, garantizase las prerrogativas del Rey y los derechos del pueblo, no suponía verdaderamente apostar por un Senado, porque el iudex medius no tenía capacidad legislativa ni carácter representativo, pero se trataba de una imitación de las facultades y, sobre todo, del espíritu de equilibrio de la Cámara Alta $^{37}$

En otros casos, la combinación de tradición y modernidad se lograba diseñando un régimen representativo mixturado con un gobierno de consejos. Así, Juan Bosmeniel proponía formar unas Cortes estamentales que compartirían sus funciones legislativas con un Consejo Soberano del Estado ${ }^{38}$ (también estamental) y un Consejo Supremo de administración de Justicia de España e Indias $^{39}$ (reunión de todos los antiguos Consejos). En este caso, los Consejos asumían el papel de Cámara Alta en un sentido más propio, porque participaban en la función legislativa como medio indispensable para garantizar el equilibrio constitucional.

\section{II.3. El DEBATE «OFICIAL" SOBRE EL BICAMERALISMO}

En la Junta Central el debate sobre el bicameralismo atravesó dos fases; en la primera, la discusión giró en torno a la convocatoria o no por estamentos, en la segunda, aclarado este extremo, ya se dilucidó si los representantes debían concurrir a una o dos Cámaras.

Como ya se ha mencionado, Calvo de Rozas - para ser justos, retomando una idea ya planteada por Jovellanos - propuso la convocatoria de Cortes (15 de abril de 1809), lo que ocasionó la redacción de un proyecto de Decreto por Quintana (entre el 16 y el 24 de abril de 1809), que se sujetó al dictamen de los vocales. El proyecto indicaba que las Cortes se reunirían del modo que la Junta determinase, pero teniendo en cuenta "la diferencia y alteraciones que han sobrevenido desde el tiempo en que se celebraban legítimamente aquellas

36 Ayuntamiento de Cádiz, 30 de septiembre de 1809. En: Federico Suárez, Cortes..., op. cit., vol. III, pág. 132; Pedro Alcántara Corrales, Málaga, 29 de noviembre de 1809, en: Miguel Artola, Los orígenes..., op. cit., vol. II, pág. 464.

37 Una postura intermedia fue adoptada por Francisco Pérez Muñoz, que pretendía que se creara una Cámara Suprema de Justicia "intermedia entre la Potestad Real y la Cámara representativa", cuyos miembros serían elegidos por el Rey entre personas que hubieran realizado grandes servicios a la patria, y en la que podían integrarse también los Príncipes de la Casa Real. Aunque parece que se trata de un tribunal, el informante señalaba que tenía capacidad de sanción legislativa (art. 16). Vid. el informe en Ignacio Fernández Sarasola, Proyectos constitucionales en España (1786-1824), op. cit., págs. 460 y ss.

38 Las Cortes propondrían los asuntos de guerra y paz, alianza, nuevos impuestos y creación de tropas, correspondiendo la decisión final al Consejo Soberano del Estado (Capítulo IX, art. 1). En Ignacio Fernández Sarasola, Proyectos constitucionales en España (1786-1824), op. cit., págs. 497-498.

39 La creación de leyes nuevas (no fundamentales), su enmienda o derogación serían examinadas por este Consejo que las remitiría con su opinión al Consejo Soberano del Estado, órgano que adoptaría la decisión definitiva (Capítulo X, art. 2). En ibídem, pág. 498. 
juntas,$^{40}$. La mayoría de los vocales partidarios de las Cortes indicaron la necesidad de incrementar las ciudades con derecho a voto ${ }^{41}$, e incluso hacer un llamamiento a los territorios americanos ${ }^{42}$, pero uno de los miembros de la Junta planteó ya el problema de la representación estamental: Jovellanos. Influido por el Ensayo bistórico-crítico de Francisco Martínez Marina, por quien profesaba una admiración profunda ${ }^{43}$, el prócer asturiano redactó su célebre Consulta sobre la convocación de las Cortes por estamentos (21 de mayo de 1809) que, como su propio título indica, vindicaba la necesidad de ajustarse a la tradición nacional, llamando a Cortes a las distintas clases sociales que habían sido representadas en ellas ${ }^{44}$.

Se trazaba así una línea que sería corroborada unos días más tarde, cuando la recién creada Comisión de Cortes, de la que formaba parte (y lideraba) Jovellanos, elaboró un dictamen favorable a la convocatoria por estamentos. Discreparon los vocales Caro y Riquelme, quienes consideraban que debía seguirse no ya la tradición más arcaica y poco adecuada a los tiempos modernos, sino la más próxima, conforme a la cual sólo integraba el Parlamento los diputados de ciudades y villas ${ }^{45}$. El pleno de la Junta Central, sin embargo, se conformó con el dictamen de la Comisión de Cortes, acordando una convocatoria por estamentos.

El primer paso para formar un Senado ya estaba dado, aunque tuviese que superar nuevos escollos. Determinado que los diputados serían llamados por clases, el segundo jalón del camino consistía en determinar si habría una, dos, o incluso tres cámaras. La última de las opciones no fue defendida por ningún vocal, de modo que las discrepancias se produjeron en torno a convocar una sola Cámara, como defendería un grupo liberal de vocales, o bien dos, según

40 El proyecto en Manuel Fernández Martín, Derecho parlamentario español, op. cit., vol. I, pág. 444.

41 Véase por todos el dictamen de Valdés (13 de mayo de 1809), en ibídem, vol. I, pág. 450. En el mismo sentido, Jovellanos se encargó de elaborar un dictamen sobre las ciudades con derecho a voto, en el que incluía villas que no habían sido convocadas en las Cortes de 1789. ACD, Sección General, legajo 4, núm. 3. Lo ha reproducido Manuel Fernández Martín, en ibídem, vol. I, págs. 484-486.

42 Dictamen de Palafox (sin fecha), en ibídem, vol. I, pág. 457.

43 El Ensayo histórico-crítico sobre la legislación y principales cuerpos legales de los Reinos de León y Castilla de Martínez Marina se publicó en 1808. Jovellanos la leyó unos meses antes de evacuar el célebre dictamen sobre la convocatoria de Cortes por estamentos. Sobre este obra dijo Jovellanos a su autor: "Confieso a usted que a pesar de lo mucho que esperaba de la acreditada ciencia de usted, he hallado en ella mucho más de lo que esperaba (...) en tan vasta e importante materia, tratada a la verdad por muchos, mas por ninguno tan cumplidamente con tan abundante y preciosa doctrina y tan penetrante y docta crítica como por usted. Jovellanos, Carta a Francisco Martínez Marina, (¿Aranjuez, 14 de noviembre de 1808?), en Jovellaos, Obras completas, op. cit., vol. V, pág. 26. El gijonés recomendó su lectura a Lord Holland. Vid. Carta a Lord Holland, (Aranjuez, 2 de noviembre de 1808), en ibídem, pág. 22. Jovellanos solicitó que Marina colaborase con la Comisión de Cortes. Carta a Francisco Venegas (Sevilla, 8 de agosto de 1809), en ibídem, pág. 267.

44 El texto en Gaspar Melchor de Jovellanos, Memoria en defensa de la Junta Central, Junta General del Principado de Asturias, Oviedo, 1992, vol. II, págs. 113 y ss.

45 El texto en Manuel Fernández Martín, Derecho parlamentario español, op. cit., vol. I, págs. 480-481. 
pretendía un sector reformista, liderado por Jovellanos. El asunto pasó en primer lugar por la Junta de Ceremonial, que votó a favor de una sola Cámara. Aunque el ejemplo de la Asamblea Nacional francesa había sido poco edificante, decía el informe, la situación producida en el país vecino se debía, precisamente, a que allí las tres clases estaban en conflicto, lo que había provocado que el tercer estado tratase de dominar a los sectores privilegiados, trayendo consigo la anarquía. Para evitar en España igual contienda, era más conveniente que las tres clases se reunieran en una sola Cámara y trabajasen codo con codo; además, el veto que acompañaba a las Cámaras Altas era siempre un obstáculo, ya que suponía un triunfo de la minoría (puesto que el Senado era siempre poco numeroso), sobre la mayoría de la Cámara Baja ${ }^{46}$. Los miembros de la Junta de Ceremonial emitieron sus votos por escrito apoyando su postura. Los argumentos eran principalmente tres. En primer lugar, la teoría del "mal menor", sostenida por el liberal Polo y Alcocer; contrario a la convocatoria por estamentos, ya que ésta se hallaba decretada el único modo de mantener el principio de igualdad era, al menos, que los tres estamentos concurrieran en una sola Cámara ${ }^{47}$. Una segunda postura fue la de la "armonía": crear dos Cámaras suponía fomentar la discordia, incrementada por la presencia del veto ${ }^{48}$. Finalmente, se utilizó el razonamiento de que las clases privilegiadas defenderían mejor sus propios intereses oponiéndose cara a cara con su principal rival, el pueblo llano ${ }^{49}$.

Tratado el asunto por la Junta de Ceremonial, pasó después a la Comisión de Cortes, en la que la voz de Jovellanos era dominante y que optaría por el bicameralismo $^{50}$ en su dictamen de 18 de diciembre de $1809^{51}$. El pleno de la Junta

46 El informe en ibídem, vol. I, págs. 539-544.

47 Voto de Polo y Alcocer (sin fecha), en ibídem, vol. I, págs. 528-529.

48 Votos de Capmany (4 de diciembre de 1809), en ibidem, págs. 530-531; Voto de Ramírez Cotes (3 de diciembre de 1809), en ibídem, págs. 533-535.

49 Voto de Ramírez Cotes (3 de diciembre de 1809), en ibídem, pág. 135; Voto de Manuel Abella (sin fecha), en ibidem, pág. 537. Mención aparte merece el vocal Torres, quien consideraba que la discusión debía ser entre convocar una o tres cámaras, optando por la primera solución. Desde luego no faltaba lógica a su voto, puesto que la tradición era más conforme con cualquiera de estas dos soluciones que con el bicameralismo. El voto en ibídem, pág. 538.

50 Jovellanos escribía entonces a Lord Holland (6 de diciembre de 1809): "Precisamente nos hallamos en el punto de resolver el punto de la formación de los dos estamentos. El mayor número de los que han escrito sobre esto se inclina a una sola cámara, y ninguno a tres; pero la Comisión de Cortes ha adoptado las dos, y va a proponer su dictamen a la Junta Suprema, con grande esperanza de que sea sancionado por ella. La convocatoria, la forma de los poderes, la fórmula del juramento, la instrucción para las elecciones y el manifiesto que debe acompañar a la convocación se está arreglando, y el 1. ${ }^{\circ}$ de enero se expedirán las órdenes, cumpliendo nosotros, a costa de mil afanes y contradicciones, nuestra promesa". Carta a Lord Holland (Sevilla, 6 de diciembre de 1809), en Jovellanos, Obras completas, op. cit., vol. V, pág. 327. Apenas unos días más tarde comentaba: "Todo puesto de nuestra parte para la convocación de las Cortes; acordada por nosotros la forma de la convocatoria, la instrucción para las elecciones, la forma de los poderes, etc. Esta noche se presentará todo a la Suprema, pasará a prensa, y el 1. de enero irá andando por esas provincias. Quid ultra debui facere? No sé si los franceses nos dejarán consumar esta grande obra; ella será la redención de España. El Congreso está convocado para el nuevo San Carlos: locus tutus et non suspectus, como dicen los Fueros de Aragón". Carta a Tomás de Verí(Sevilla, 12 de diciembre de 1809), en ibídem, pág. 329. 
Central se hallaba, entonces, con dos pareceres discrepantes: el de la Junta de Ceremonial, partidario del unicameralismo, y el de la Comisión de Cortes, favorable a la existencia de una Cámara Alta. Al final optó por el primer dictamen, para disgusto de Jovellanos. Pero el gijonés, tenaz en las resoluciones que adoptaba - como diría Toreno ${ }^{52}$ - no cejó en su empeño y el 8 de enero de 1810, la Comisión de Cortes remitió a la Junta Central una nueva consulta sobre el mismo asunto insistiendo en la necesidad de formar una Cámara Alta. El argumento principal, entresacado del constitucionalismo británico, era la necesidad de lograr un equilibrio ${ }^{53}$ y logró por fin convencer a la Junta Central, que aprobó el dictamen el 20 de enero de 1810.

Del proceso mencionado puede deducirse con facilidad que nadie en la Junta Central insistió tanto como Jovellanos en la necesidad de instaurar un bicameralismo. El asturiano tiene el mérito de ser el primer gran defensor del Senado en España, aunque, en realidad, no se trataba tanto de una idea originaria suya, como la traslación del ideario sostenido por dos amigos británicos, Lord Holland y John Allen. En efecto, la influencia que éstos ejercerán en Jovellanos sobre este asunto (que es tanto decir como el influjo en el primer intento de implantar el bicameralismo) es mucho más determinante de lo que en ocasiones se ha llegado a decir ${ }^{54}$. Lord Holland, sobrino del reputado líder whig Charles James Fox, había parlamentado en infinidad de ocasiones con el gijonés, y en

51 Manuel Fernández Martín, Derecho parlamentario español, vol. I, págs. 544-549.

52 Así lo retrataba Toreno: "Suave de condición, pero demasiadamente tenaz en sus propósitos, a duras penas se le desviaba de lo una vez resuelto". José María Queipo de Llano, Conde de Toreno, Historia del levantamiento, guerra y revolución de España, op. cit., 1953, págs. 133-134. Toreno señala que Jovellanos estaba persuadido de la necesidad de que en un Monarquía existiese "un poder intermedio entre el Monarca y el pueblo. Así, estuvo siempre por la opinión de una representación nacional dividida en dos cámaras".

53 "La Comisión no puede dejar de recordar a Vuestra Majestad que una sola Asamblea se distinguirá siempre por su tendencia a la democracia, y por lo mismo es muy ajena de toda Constitución monárquica. Porque ¿qué freno, qué contrapeso puede inventar la política capaz de detener esta tendencia, continuamente dirigida contra el Gobierno de uno solo? Si en ella predomina una fracción democrática, el Soberano, despojado poco a poco de sus prorrogativas, apenas conservará más que el solo título de su dignidad; pero si, por el contrario, los artificios de las Cortes o medios de corrupción que puede tener un Soberano le ganaren un partido predominante en las Cortes, ¿quién no temerá que corra sin obstáculo, primero a la arbitrariedad y luego al despotismo? No puede, pues, existir una Monarquía sin clases jerárquicas, ni existir éstas sin una Representación separada que, además del derecho de conservarse, tenga el de interponerse entre el Soberano y el pueblo, para contener a uno y a otro, y mantener en fiel la balanza de la justicia y el equilibrio de la libertad.". Dictamen de la Comisión de Cortes que acompañó a las convocatorias por estamentos (8 de enero de 1810), en Manuel Fernández Martín, Derecho parlamentario español, op. cit., págs. 590-599.

54 Aunque admirador de Montesquieu y partidario de un gobierno equilibrado, en realidad Jovellanos no se refirió al bicameralismo hasta 1809, a partir de las conversaciones que tuvo con Lord Holland y Allen. Quizás haya sido el profesor Tomás y Valiente quien haya valorado en mayor medida esta influencia de Holland y Allen en Jovellanos. Vid. Francisco Tomás y Valiente, "Las Cortes de España en 1809, según un folleto bilingüe cuya autoría hay que atibuir a un triángulo compuesto por un Lord inglés, un Ilustrado español y un joven médico llamado John Allen", en Francisco Tomás y Valiente, Obras completas, C.E.C., Madrid, 1998, vol. V, pág. 4718. 
su correspondencia le instaba hasta la extenuación para que activase la formación de unas Cortes que debían ser bicamerales ${ }^{55}$. Por su parte, John Allen (médico de Lord Holland), había asumido el compromiso de elaborar un plan de reunión de Cortes que conjugase la tradición española con las reformas oportunas que debían practicarse. Este plan, remitido a Jovellanos a medida que se iba realizando, vio después la luz con el título de Suggestions on the Cortes, y en él se expone con claridad la idea bicameral que acabaría por convencer al gijonés ${ }^{56}$.

Pero el convencimiento no fue instantáneo, sino fruto de un proceso, porque Jovellanos no pensaba, en un primer momento en convocar Cortes bicamerales. En efecto, inicialmente el asturiano sólo deseaba que la Junta Central realizase mínimas modificaciones en la convocatoria de Cortes (como incrementar las ciudades llamadas a la Asamblea) basándose en una sólida argumentación: la Central era un órgano ejecutivo, y además interino y anómalo, por lo que no podía abordar reformas de envergadura, que debían adoptar las propias Cortes. Cuando John Allen le envía su propuesta bicameral a Jovellanos, éste se opone: una enmienda de tal calado no podía ser decretada por la Junta Central, sino todo lo más propuesta a las Cortes una vez reunidas ${ }^{57}$. A continuación, el polígrafo asturiano entró en lo que podría llamarse como una fase dubitativa, en la

55 La insistencia de Lord Holland sobre la necesidad de que las Cortes se reuniesen, y que lo hicieran cuanto antes, resultaba casi obsesiva. Apenas hay misivas en las que no pidiese a Jovellanos que se concluyera la grand affaire (expresión con la que se refería a la convocatoria de Cortes). Véasen a modo de ejemplo las siguientes cartas de Holland al gijonés: Sevilla (principios de abril de 1809), en Jovellanos, Obras completas, op. cit., vol. V, pág. 86; Jerez de la Frontera (17 de abril de 1809), en ibídem, pág. 117; Cádiz ( 5 de mayo de 1809), en ibídem, pág. 129; Sevilla (16 de mayo de 1809), en ibídem, pág. 137; Sevilla (17 de mayo de 1809), en ibídem, pág. 141; Cádiz (17 de mayo de 1809), en ibídem, pág. 143; Cádiz (19 de mayo de 1809), en ibídem, pág. 148; Cádiz (20 de mayo de 1809), en ibídem, pág. 151; Cádiz (21 de mayo de 1809), en ibídem, pág. 154; Cádiz (22 de mayo de 1809), en ibídem, pág. 160; Cádiz (23 de mayo de 1809), en ibídem, pág. 161; Cádiz (28 de mayo de 1809), en ibídem, pág. 169; Badajoz ( 5 de julio de 1809), en ibídem pág. 241; Lisboa (17 de julio de 1809), en ibídem, pág. 254; Londres (31 de agosto de 1809), en ibídem, pág. 276; Londres (6 de septiembre de 1809), en ibídem, pág. 281; Londres (8 de septiembre de 1809), en ibídem, pág. 284; Londres (18 de octubre de 1809), en ibídem, pág. 307; Londres (1 de noviembre de 1809), en ibídem, pág. 314 ; ¿Londres? (28 de noviembre de 1809), en ibídem, pág. 324; Londres (13 de diciembre de 1809), en ibídem, pág. 332; Amphill Park (26 de diciembre de 1809), en ibídem, pág. 335. A la insistencia de Lord Holland, Jovellanos siempre replicaba con templanza, diciendo que la convocatoria de Cortes exigía aclarar muchos extremos que no debían juzgarse con precipitación. No obstante, disuelta la Junta Central, Jovellanos reconoció a Lord Holland que tendría que haber seguido sus consejos y haber procurado una reunión más pronta de las Cortes. Carta a Lord Holland (Muros, 18 de julio de 1810), en ibídem, pág. 398.

56 Las Suggestions, publicadas en Londres (Suggestions on The Cortes, E. Blackader Printer, London, 1809), fueron traducidas al castellano por Ángel de la Vega Infanzón (Insinuaciones sobre las Cortes, E. Blackader, London, 1809). Las he incluido en Ignacio Fernández Sarasola, Proyectos constitucionales en España (1786-1824), op. cit., págs. 587 y ss. Anteriormente, Holland y Allen habían elaborado un plan en el que ofrecían tanto la alternativa del unicameralismo como la del bicameralismo, según se considerase mejor. Pronto abandonaran la primera de estas opciones. El texto en Jovellanos, Escritos políticos, en Obras Completas, IFES XVIII, Oviedo, 2006 (en prensa).

57 Carta a Lord Holland (Sevilla, 7 de junio de 1809), en Jovellanos, Obras completas, vol. V, pág. 197. 
que empezó a solicitar a Lord Holland que le aclarase los beneficios que conllevaban unas Cortes bicamerales. Las preguntas planteadas muestran a un Jovellanos todavía confuso sobre las ventajas del sistema británico ${ }^{58}$, por lo que debe pensarse que, más aún que la lectura de Montesquieu, De Lolme o Blackstone, fueron Lord Holland y Allen los que lo convirtieron en acólito del bicameralismo. Así, los amigos ingleses de Jovellanos empezaron a narrarle las excelencias del bicameralismo: una Cámara Alta, intermedia entre el Rey y la Cámara Baja, con un derecho de veto para frenar las acometidas democráticas era el mejor mecanismo para seguir los pasos prudentes de Gran Bretaña, y no caer en los excesos de la Revolución Francesa ${ }^{59}$. En cuanto a convocar inmediatamente las primeras Cortes en dos Cámaras, Allen era claro: se trataba de evitar discordias, ya que, si se dejase a las primeras Cortes este debate (como pretendía Jovellanos), el enconamiento y las discrepancias podrían hacer que naufragase la tentativa ${ }^{60}$.

Entre junio y diciembre de 1809 estos argumentos acabaron por convencer al célebre polígrafo gijonés y, como ya hemos visto, desde entonces se convirtió en el principal vindicador del Senado de corte británico. Cuando en enero de 1810 tuvo que redactar el Último Decreto de la Junta Central, quiso dejar asegurado que las Cortes se reunirían en dos Cámaras ${ }^{61}$. Vana previsión. Este decreto no llegó a circular, sin que hoy se sepa muy bien quién fue el responsable de la pérdida ${ }^{62}$. En consecuencia, el Parlamento que pasaría a la historia

58 "Porque en lo demás, y en cuanto a la ventaja de la representación en dos Cámaras separadas, soy del parecer del mismo Mr. Allen, por más que crea dificil obtener este punto. ¿No lo será, por ejemplo, que los representantes del pueblo le resistan, no viendo en la Cámara Alta otra cosa que un contrapeso de su poder, y temiendo el influjo de unos Cuerpos a quienes la actual opinión pública dan, por su riqueza y autoridad, tan grande influjo? Y, de otra parte, ¿no lo será amalgamar en uno solo dos brazos que habian representado separadamente sus clases, y cuyos intereses, si uniformes en algunos, estarian divisos o encontrados en otros puntos? ¡Ah, mi Mr. Allen y usted, mi querido Lord, socorro! Alúmbrenme, les pido, en esta perplejidad; alúmbrenme, sobre todo, en cuanto a las ventajas con que esta reunión se puede presentar a las clases privilegiadas y aquéllas que tendrá el pueblo para no temerla". Carta a Lord Holland (Sevilla, 11 de junio de 1809), Obras completas, vol. V, núm. 1893, págs. 204-205. Las dudas suscitadas obligarían a Allen a incrementar las Sueggestions para responder adecuadamente a los interrogantes de Jovellanos. Carta de Lord Holland a Jovellanos (Cádiz, 14 de junio de 1809), en ibídem, pág. 214. Las respuestas sobre el bicameralismo las proporcionó Allen en los parágrafos 12-16 de la Parte I de las Suggestions.

59 Carta de Lord Holland a Jovellanos (Cádiz, 21 de mayo de 1809), en Jovellanos, Obras completas, op. cit., vol. V, pág. 154.

60 Cfr. John Allen, Suggestions on the Cortes, en Ignacio Fernández Sarasola, Proyectos constitucionales en España (1786-1824), op. cit., págs. 634-635.

61 "Abierto el solio — decía el artículo 15-, las Cortes se dividirán, para la deliberación de las materias, en dos solos estamentos, uno popular, compuesto de todos los procuradores de las provincias de España y América, y otro de dignidades, en que se reunirán los prelados y grandes del reino". El texto en Jovellanos, Memoria en defensa de la Junta Central, op. cit., vol. II, pág. 157.

62 Sobre este punto sigue siendo imprescindible consultar el detallado trabajo de Federico Suárez, El proecso de la convocatoria a Cortes (1808-1810), Eunsa, Pamplona, 1982, págs. 427 y ss. El decreto no apareció hasta el 31 de octubre, momento en el que lo encontraron los encargados de recopilar los papeles que habían pertenecido a la Junta Central. Sin embargo Blanco White, quien habría recibido una copia del decreto, la publicó unos días antes en El Español, núm. 6, 30 de septiembre de 1810, págs. 447-452. 
como "Cortes de Cádiz" se reuniría en una sola Cámara. El primer intento de implantar un Senado había fracasado, y el liberalismo partidario del pensamiento revolucionario francés había salido triunfante.

\section{EL SENADO OCULTO POR EL MODELO REVOLUCIONARIO}

\section{III.1. La CUeSTIÓN DEL BICAMERALISMO EN LAS CORTES DE CÁDIZ}

Tras todos los desvelos políticos, Jovellanos no logró finalmente que las Cortes de Cádiz se reuniesen en dos Cámaras, y el fracaso le supuso una gran decepción. Para él, el unicameralismo apuntaba hacia las posturas más radicales, el triunfo de las doctrinas más extremas (Rousseau, Mably, Sydney...) y, en fin, abría el camino hacia la "democracia", según él denominaba ${ }^{63}$.

Alejado Jovellanos de las Cortes de Cádiz, su postura sería defendida en el seno de la Asamblea por los diputados realistas ${ }^{64}$ en los que se evidenciaba una mixtura entre el tradicionalismo y la admiración por el sistema británico de checks and balances ${ }^{65}$. En realidad, entre los realistas existía una confusión evidente entre la teoría del estado mixto, la doctrina de separación de poderes y el recurso a las Cortes tradicionales españolas ${ }^{66}$. El objetivo de este grupo era, en principio, recuperar las antiguas Cortes estamentales. Con ello, a su entender, se restituiría un Estado Mixto, en el que se conjugaban

63 Jovellanos, Carta a Lord Holland (Muros de Noya, 5 de diciembre de 1810), en Obras Completas, op. cit., vol. V, pág. 422.

64 Así lo reconocía Jovellanos: "si yo he resuelto retirarme, es por reflexionar que ya nada valgo para ese teatro, donde mis viejas ideas estarán en cabezas menos viejas que la mía, y ésta poco firme para llevar con templanza las que hierven en otras más mozas". Carta a Alonso Cañedo $y$ Vigil (Gijón, agosto de 1811), Obras completas, vol. V, pág. 484. Sus ideas fueron sostenidas principalmente por su sobrino, Alonso Cañedo. Sin embargo, no se puede afirmar que la Memoria en defensa de la Junta Central (principal texto político de Jovellanos) hubiese influido directamente en los diputados realistas. Todavía en agosto de 1811 (cuando ya se habían discutido artículos tan relevantes como el de la soberanía), Jovellanos no la había publicado, y apenas si daba noticia de ella a Alonso Cañedo. Carta a Alonso Cañedo (Gijón, agosto de 1811), en Jovellanos, Obras completas, op. cit., vol. V, pág. 483. Sobre la adscripción de los realistas a las ideas de Jovellanos, vid. Joaquín Varela Suanzes, La teoría del Estado en los origenes del constitucionalismo hispánico (Las Cortes de Cádiz), C.E.C., Madrid, 1983, págs. 13 y ss., y 82 y ss.; íd., "Las Cortes de Cádiz: representación nacional y centralismo", en Las Cortes de Castilla y León. 1188-1988, Cortes de Castilla y León, Valladolid, 1990, págs. 223-226.

65 Cfr. Joaquín Varela Suanzes, "Los modelos constitucionales en las Cortes de Cádiz", en François-Xavier Guerra (director), Las revoluciones hispánicas: independencias americanas y liberalismo español, Editorial Complutense, Madrid, 1995, págs. 245 y ss.; íd., "El debate sobre el sistema británico de gobierno en España durante el primer tercio del siglo XIX", en Javier Avarado (coord.), Poder, economía, clientelismo, Marcial Pons, Madrid, 1997, págs. 97 y ss.; el mismo texto también en: en José María Iñurritegu / José María Portillo, Constitución en España: orígenes y destinos s.E.P.C., Madrid, 1998, págs. 79 y ss.

66 Vid. Santos Coronas González, "Los orígenes del sistema bicameral en España", en Juan Cano Bueso (edit.), Materiales para el estudio de la Constitución de 1812, Tecnos, Madrid, 1989, págs. 202-203. 
Monarquía, Aristocracia (Senado) y democracia (Cámara Baja). Los tres órdenes quedarían de este modo equilibrados entre sí, evitando de esta manera, mediante controles recíprocos, la preponderancia de una de las clases sociales ${ }^{67}$. El Senado era, pues, una Cámara Aristocrática que, siguiendo las teorías de Montesquieu, servía como freno de la Cámara Baja a través del veto de las leyes; lo que era tanto como decir que la aristocracia —clase más conservadora e instruida - retenía los ímpetus de la irreflexiva Cámara democrática.

Pero los liberales lograron imponer su criterio unicameral, basado en el principio de igualdad, en el individualismo y en la soberanía nacional, elementos, todos ellos, que suponían una negación de las clases privilegiadas y, por consiguiente, la imposibilidad de contar con una Cámara Alta estamental ${ }^{68}$. Tampoco fueron partidarios de un Senado compuesto por personalidades, como había propuesto Flórez Estrada a imitación de la Constitución francesa del año III, puesto que rechazaban la idea de equilibrio y doble deliberación. No existía una desconfianza en la representación nacional que obligara a que sus decisiones fuesen sujetas a nuevos debates en otra Cámara; siendo la nación soberana, sus decisiones - expresadas por las Cortes - era siempre voluntad general y, por consiguiente, rectas y acertadas. Pero si se deseaba algún freno, al menos la Constitución ya había previsto el veto suspensivo del Rey, con el que algunos diputados, como Toreno, tampoco estaban de acuerdo ${ }^{69}$.

La decisión constituyente no fue vista con buenos ojos allende de nuestras fronteras. Blanco White, desde Londres, asumió la crítica que ya había vertido Jovellanos. El sevillano, que en su día al frente del Semanario Patriótico había profesado un radicalismo cortado por el molde francés, había evolucionado en Londres hacia la anglofilia ${ }^{70}$. De este modo, la idea de contar con una Cámara

67 Véanse las intervenciones de Cañedo, Borrull e Inguanzo en Diario de Sesiones n. ${ }^{\circ}$ 345, 12 de septiembre de 1811, vol. III, pág. 1820-1824; Diario de Sesiones n. ${ }^{\circ} 346,13$ de septiembre de 1811, vol. III, págs. 1837-1839.

68 La oposición a la Cámara Alta fue total. Argüelles decía que el bicameralismo no hallaba precedente en la historia española, por lo que sería una "odiosa novedad" que mortificaría al tercer estado. Diario de Sesiones, núm. 345, 12 de septiembre de 1811, págs. 1827-1830. Para Ortiz el simple hecho de formar Cortes estamentales supondría destruir todo lo implantado por la Asamblea gaditana (ibídem, pág. 1834). El impulsivo Toreno (recuérdese que era el diputado más joven de las Cortes) negaba el valor del artificial sistema de checks and balances descrito por Montesquieu, al que consideraba "atrasado" en sus ideas sobre el sistema representativo (ibidem, pág. 1835).

69 Diario de Sesiones, n. ${ }^{\circ}$ 346, 13 de septiembre de 1811, vol. III, pág. 1835; Diario de Sesiones n. ${ }^{\circ} 336,3$ de septiembre de 1811, vol. III, pág. 1750-1751: "¿Cómo una voluntad individual se ha de oponer a la suma de voluntades de los representantes de la Nación? ¿No es un absurdo que solo una voluntad detenga y haga nula la voluntad de todos? Sobre la postura particular del Conde de Toreno en las Cortes de Cádiz resulta imprescindible la lectura del reciente libro de Joaquín Varela Suanzes, El Conde de Toreno. Biografía de un liberal (1786-1843), Marcial Pons, Madrid, 2005, págs. 75 y ss. Igualmente, del mismo autor, Conde de Toreno. Discursos parlamentarios, Colección Clásicos Asturianos del Pensamiento Político, núm. 15, Junta General del Principado de Asturias, Oviedo, 2003.

70 Vid. Joaquín Varela Suanzes, "Un precursor de la Monarquía Parlamentaria: Blanco-White y El Español (1810-1814)", Revista de Estudios Políticos, núm. 79, 1993, págs. 101 y ss. 
Alta a imagen y semejanza de la Cámara de Lores le parecía un aspecto sustancial para lograr un sistema equilibrado como el británico ${ }^{71}$. De ahí que se quejara del unicameralismo instaurado en la Constitución de 1812, que suponía una concesión hacia el dominio incondicional de la Asamblea.

También en Inglaterra algunas de las más prestigiosas publicaciones criticaron el unicameralismo gaditano. Coincidieron en este punto tanto la prensa tory, representada por la Quarterly Review, como la whig, expuesta en la Edinbugh Review. A pesar de la diferencia de ideario entre ellas, ambas consideraban imprescindible la presencia de una Cámara Alta aristocrática para lograr un equilibrio constitucional que faltaba en España ${ }^{72}$. Apenas Jeremy Bentham alabó el unicameralismo que habían proclamado los españoles en su Constitución; una postura que explica el predicamento que el filósofo británico tuvo entre los exaltados durante el Trienio Liberal ${ }^{73}$.

En Francia, especialmente a partir de 1814, también se asumió la crítica implacable del unicameralismo gaditano, común tanto al liberalismo doctrinario como al pensamiento contrarrevolucionario y ultra. En efecto, entre los liberales doctrinarios y el círculo de Coppet se sostuvo la idea de que la Constitución del 12 tenía, entre otras lacras, la del unicameralismo. Así, Alcalá Galiano narraba cómo en su primera entrevista con Madame de Staël, ésta le había mencionado que la Constitución de Cádiz estaba muy mal construida, ya que le faltaba un Senado aristocrático ${ }^{74}$. Por su parte, Guizot —que llegaría a entablar amistad con el Conde de Toreno en la fase moderada de éste- veía idéntico problema en el texto español ${ }^{75}$. Más duro en sus críticas era el ultra conservador Chateaubriand, al que poco o nada agradaba de la Constitución de 1812, empezando por la declaración misma de la soberanía nacional. Fiel defensor de los privilegios de una aristocracia de la que formaba parte, el literato romántico consideraba desastroso la ausencia en España de un Senado nobiliar ${ }^{76}$.

Incluso quienes no eran tan severos con la Constitución de Cádiz, como el liberal Lanjuinnais, echaban de menos un Senado. Lanjuinnais habría admitido el proyecto constitucional de Flórez Estrada en este punto, ya que el Senado que él deseaba para España no tenía nada que ver con la Cámara Alta aristo-

71 El Español, vol. V, núm. 29, 30 de septiembre de 1812, págs. 345-350; El Español, vol. VII, julio de 1813, pág. 11. Vid. también su artículo en la Quarterly Review, vol. XXIX, Abril-Julio 1823, pág. 276.

72 Quarterly Review, vol. XXVIII, octubre-enero 1822-1823, págs. 548, 555 y 556; Edinburgh Review, vol. XXIII, núm. 46, septiembre 1814, pág. 362.

73 La Sociedad Patriótica La Cruz de Malta llegó a nombrar a Bentham miembro honorífico. Alberto Gil Novales, Las Sociedades Patrióticas (1820-1823), Tecnos, Madrid, 1975, vol. I, pág. 101.

74 Vid. Antonio Alcalá Galiano, Memorias, en Obras escogidas de D. Antonio Alcalá Galiano, B.A.E., vol. LXXXIII (I), Atlas, Madrid, 1955, pág. 429.

75 Françoise Guizot, Du gouvernement de la France depuis la Restauration, et du ministère actuel, Librairie Française de Ladvocat, Paris, 1820, págs. 255-256.

76 François René de Chateaubriand, Congrès de Vérone; Guerre d'Espagne de 1823 ; Colonies espagnoles, en Oeuvres complètes de Chateaubriand, vol. XII, Acamédia, Paris, 1997 (basada en la edición de Garnier, París, 1861), Chapitre IV. Esta obra se ha consultado a partir de su reproducción www en el URL: http://gallica.bnf.fr/classique/ 
crática que proponían doctrinarios y ultras. Antes bien, se trataba de una Cámara de ancianos, muy similar a la prevista en el Directorio francés ${ }^{77}$.

\section{III.2. LOS INTENTOS DE SUPERAR EL MODELO REVOLUCIONARIO. LA NECESIDAD DE HALLAR UN SENADO}

Como es bien sabido, tras la caída de la Constitución de Cádiz en 1814, el liberalismo empezó a replantearse el modelo revolucionario que la había gestado. El resultado sería la escisión liberal en dos grupos ya perfilados en 1821: los exaltados, herederos del liberalismo de las Cortes de Cádiz y partidarios de aplicar —e incluso agudizar- el modelo cuasi-asambleario que subyacía al texto de 1812, y los moderados, que ya empezaban a ligarse al liberalismo doctrinario y buscaban superar el modelo revolucionario de 1812 y sustituirlo por un gobierno construido sobre el patrón británico (ya de equilibrio constitucional, ya como sistema parlamentario $)^{78}$. Y puede que nada ejemplifique mejor este distanciamiento que la postura en torno al Senado.

Sin embargo, antes incluso del Trienio Constitucional (1820-1823), ya se diseñó un proyecto de Senado en el que la influencia del liberalismo doctrinario, de Constant y de Destutt de Tracy resulta evidente. En 1819 un sector liberal preparó un movimiento insurreccional que debía extenderse desde Cádiz, a partir de las tropas dispuestas a embarcarse a América para reprimir el levantamiento de las colonias. El intento fracasaría debido a la traición de uno de los jefes militares que preparaban el golpe, Enrique O'Donnell, Conde de La Bisbal, en lo que fue conocido como la "Sorpresa del Palmar". Pues bien, esta revuelta frustrada se había acompañado de un premeditado plan constitucional que se hallaba tan distante del modelo de 1812 como del absolutismo fernandino ${ }^{79}$. Así se aprecia en uno de los documentos nucleares de la insurrección, intitulado como Instrucciones: en su primera parte acometía una severa crítica al despotismo de Fernando $\mathrm{VII}^{80}$, en tanto que en una segunda sección le correspondía

77 Jean Denis, Comte de Lanjuinais, Vues politiques sur les changemens a faire a la Constitution d'Espagne afin de la consolider, spécialement dans le Royaume des Deux-Sicilies (1821), en Victor Lanjuinais (edit.), Ses ouvres: avec une notice biográphique, Dondey-Dupré, Paris, 1832, págs. 537-550.

78 Cfr. Joaquín Varela Suanzes, "La monarquía imposible: la Constitución de Cádiz durante el Trienio", Anuario de Historia del Derecho Español, tomo LXVI, 1996, págs. 653 y ss.

79 Sobre el proceso insurreccional que gestó este proyecto constitucional, vid. Claude Morange, "El programa político de la conspiración de 1819", Trienio, núm. 39, 200, págs. 31 y ss.; id., "Un proyecto constitucional ignorado (1819)", Comunicaciones del Congreso internacional sobre "Orígenes del liberalismo. Universidad, Política, Economía", celebrado en la Universidad de Salamanca del 1 al 4 de octubre de 2002 (edición en CD-Rom). El profesor Morange ha sido quien ha rescatado del olvido este importante texto. En breve publicará un libro con todos los documentos relativos al mismo, y un interesante y amplio estudio de ellos.

80 Esta crítica se complementaba con un segundo documento, titulado Manifiesto insurreccional contra el Tirano que imitaba el modelo argumentativo de la Declaración de Independencia norteamericana de 1776: afirmación de los derechos de los pueblos para cambiar el gobierno; relación de los actos tiránicos del Rey y reconocimiento del derecho de resistencia. Vid. mi introducción al texto en Ignacio Fernández Sarasola, Proyectos constitucionales en España (1786-1824), op. cit., págs. 320-321. 
a la Constitución de 1812 sujetarse a la censura. En lo que ahora nos atañe, las Instrucciones señalaban que uno de los defectos "disolventes" del texto gaditano, favorecedores de la anarquía y el despotismo, era la ausencia de una segunda Cámara de reflexión, sin la cual el Parlamento carecía de freno. La presencia del veto regio, según los autores del texto, no era sustitutivo del Senado puesto que en realidad lo que hacía era comprometer la inviolabilidad regia.

Su propuesta, por tanto, era establecer el bicameralismo siguiendo el modelo que se aplicaba en las naciones más avanzadas: Gran Bretaña y Estados Unidos, desde luego, pero también Francia que, desde 1814, se había decidido por el bicameralismo apenas ensayado en la Constitución de 1795 con un sesgo muy distinto. El programa revolucionario de 1819 culminaba con un texto capital; un proyecto de Constitución que recibía el altisonante nombre de "Acta Constitucional de los Españoles de ambos hemisferios" ${ }^{81}$. En él se abandonaba el tradicional nombre de "Cortes" y se designaba al Parlamento como "Poder Legislativo". Éste se dividía en dos Cámaras: la Cámara perpetua y la Cámara temporal. Los miembros de la primera se designaban conforme a un procedimiento mixto aproximado al que después diseñaría la Constitución de 1869, en el que las provincias elaboraban listas de candidatos, de entre las cuales el Rey escogía a los senadores (cinco por provincia), siendo luego el cargo de carácter hereditario. A pesar de articular este procedimiento de elección, el Acta Constitucional se acompañaba de un proyecto de Decreto que fijaba quiénes debían componer el primer Senado, a fin de garantizar una composición igual de todos los "partidos" como muestra del talante conciliador de los autores ${ }^{82}$.

Esta Cámara Alta participaba en el poder legislativo, tanto con la facultad de iniciativa como a través de un veto suspensivo. Sin embargo, también disponía de atribuciones propias de un Senado napoleónico, como la conservación constitucional, así como otros cometidos propios de los sistemas bicamerales, como el enjuiciamiento de los ministros en un clásico procedimiento de impeachment. En este último se seguía la doctrina de Constant conforme a la cual la Cámara Alta debía tener discrecionalidad a la hora de calificar el delito y determinar la pena ${ }^{83}$. El propio nombre "Cámara perpetua" evoca la idea de que se trataba de una Cámara conservadora, en una línea muy semejante a lo que

81 El Acta Constitucional, así como otros documentos complementarios se encuentran reproducidos en Ignacio Fernández Sarasola, Proyectos constitucionales en España (1786-1824), op. cit., págs. 317-363.

82 Aparte del Decreto, en el que se indicaban las personas concretas que formarían el Senado, unas Instrucciones que acompañaban el proyecto constitucional señalaban cuáles eran las tendencias a las que pertenecerían estos senadores: "Liberales que siguieron las Cortes; Liberales americanos que siguieron la Independencia; Liberales que siguieron a José Bonaparte; Liberales neutros, que ni siguieron a José ni aprobaron enteramente la marcha de las Cortes; y Serviles mixtos, que tienen alguna dosis de liberalismo. Esta combinación se ha becho ingeniosamente, de modo que la coalición de dos o tres bandos se halle siempre contrabalanceda por las demás". El texto se reproduce en Ignacio Fernández Sarasola, Proyectos constitucionales en España (17861824), op. cit., págs. 336-337 (notas 3 y 4).

83 Cfr. Benjamín Constant, Principles de Politique (1815), en Euvres, Gallimard, Paris, 1957, Chapitre X, págs. 1126 y ss. 
proponía Constant, cuando hablaba de poder representativo de la continuidad $^{84}$, o el "pouvoir conservateur" descrito por Destutt de Tracy ${ }^{85}$. Es más, el proyecto de Decreto que señalaba quiénes debían componer la primera Cámara Perpetua la denominaba significativamente como "Senado Conservador"; una denominación, por cierto, en la que también había una influencia napoleónica.

Fracasado este intento bicameral, la opción del Senado volvería a plantearse ya durante el Trienio Liberal. Como he señalado, los liberales exaltados seguían fieles al modelo revolucionario de 1812, por lo que aún defendían el unicameralismo como única forma apta para organizar al Parlamento. No opinaban igual los liberales moderados, algunos de los cuales, como Argüelles o Toreno, habían sido constituyentes en 1812, pero que en 1820 opinaban de manera muy distinta, influidos ahora por la anglofilia ${ }^{86}$. La colisión entre ambos sectores tuvo en la idea de Senado uno de sus puntos capitales. Los exaltados identificaron a los moderados más conservadores — los denominados "anilleros", por pertenecer a la Sociedad de Anillo_ con los absolutistas, y les imputaron el tener preparado un proyecto constitucional que, dirigido a reemplazar a la Constitución del 12, pretendía establecer el bicameralismo. A este intento conservador, del que nunca se ha hallado prueba documental y en el que se vieron implicados por la prensa Martínez de la Rosa y Toreno, se le denominó "plan de las cámaras". Así pues, para los exaltados, el elemento más nocivo del supuesto plan era, precisamente, el intento de instaurar una segunda Cámara; Senado y absolutismo se llegaban por tanto a identificar.

En realidad, está fuera de duda que los moderados veían con buenos ojos el Senado, aunque no parece que tuviesen un plan sólido diseñado para reemplazar de inmediato a la Constitución de Cádiz ${ }^{87}$. Tampoco podían reformarla, bien porque la cláusula de intangibilidad temporal lo impedía (art. 375) ${ }^{88}$, bien porque

84 Cfr. Benjamín Constant, Principles de Politique (1815), en Euvres, op. cit., pág. 1080. El vínculo con Constant es evidente también en la configuración del poder ejecutivo : disociaba el proyecto entre el poder ejecutivo, que le correspondía a los ministros, y el poder neutro, en manos del Rey.

85 Antoine Louis Claude, Comte Destutt de Tracy, Commentaire sur l'Espirit des Lois de Montesquieu, Slatkine Reprints, Genève, 1970, Livre XI, Chapitre II, págs. 206-207.

86 Sobre el cambio operado en concreto por estos dos diputados vid. por todos Joaquín Varela Suanzes, "Agustín Argüelles en la bistoria constitucional española", Revista Jurídica de Asturias, núm. 20, 1996, págs. 7 y ss.; e íd., El Conde de Toreno. Biografía de un liberal, Marcial Pons, Madrid, 2005.

87 No obstante, Comellas menciona que el Conde de Toreno se había comunicado con el Gobierno de Villèle para tratar de buscar la vía para implantar en España un sistema constitucional a imitación de la Carta de 1814. Vid. José Luís Comellas, Los realistas en el Trienio Constitucional (1820-1823), Publicaciones del Estudio General de Navarra, Pamplona, 1958, págs. 135-137.

88 La aplicación de este límite temporal a la reforma constitucional planteó alguna observación de interés. Según un sector doctrinal, la Constitución de Cádiz no había perdido validez durante los años de absolutismo fernandino (1814-1820), sino simplemente habría quedado en suspenso, esto es, habría sido “inaplicable». Por tal motivo, en 1820 podía entenderse que habían transcurrido los ocho años que prescribía la Constitución para su reforma. Véanse en este sentido las palabras del diputado Zapata, Diario de Sesiones (Cortes de 1820), vol. I, n. ${ }^{\circ} 14,18$ de julio de 1820, pág. 187. En idéntico sentido: El Español Constitucional, agosto de 1820, pág. 82. 
no parecía el momento más adecuado, cuando los verdaderos absolutistas intrigaban para derribar no sólo la Constitución, sino todo el sistema representativo. Así pues, ante la imposibilidad de crear un Senado, los moderados buscaron otra vía alternativa: interpretar el Consejo de Estado diseñado en el texto de 1812 como si fuese un remedo de Cámara Alta ${ }^{89}$. El recurso puede parecer en principio extraño, pero no lo es tanto si se tienen en cuenta algunos detalles: en primer lugar, como vimos en su momento, ya en la "Consulta al País" algunos informantes habían tratado de ver en los consejos regios órganos intermedios que evocaban la idea del Senado; en segundo lugar, el Consejo de Estado que diseñaba la Constitución de Cádiz tenía una composición muy propia para un Senado (art. 232): parte de sus componentes debían pertenecer al clero y nobleza (dos Obispos y cuatro Grandes de España) lo que evocaba una Cámara Alta privilegiada ${ }^{90}$, mientras que el resto de componentes debían ser elegidos de entre personas de prestigio por sus conocimientos o por haber desempeñado cargos públicos, lo cual asimilaba el Consejo de Estado a un Senado de mérito; finalmente, los miembros del Consejo de Estado eran propuestos por las Cortes y elegidos por el Rey, lo cual permitía concebirlo como una especie de cuerpo intermedio entre la Monarquía y la Democracia (que representaban las Cortes). No era, pues, tan descabellada la identificación que hacían los moderados aunque estaba condenada al fracaso, puesto que, aunque la composición pudiera asimilar el Consejo de Estado con el Senado, sus funciones no tenían nada que ver. De ahí el alubión de quejas: Ramón de Salas criticó que se hubiese optado por una composición estamental del Consejo de Estado, que tan mal encajaba en una Constitución fundada sobre la soberanía nacional ${ }^{91}$; el exiliado Alcalá Galiano tampoco estaría de acuerdo con un Consejo así constituido, al que acusaba de "poseer los defectos sin las ventajas propias de una Cámara Alta, de la que aparece como una imitación desafortunada ${ }^{92}$. Algo en lo que coincidía el periódico Edinburgh Review, que consideraba al Consejo de Estado insuficiente para equipararlo con una Cámara Alta ${ }^{93}$.

89 Vid. las intervenciones parlamentarias de los diputados Zapata (Diario de Sesiones $n$. $^{\circ} 104$, 16 de octubre de 1820, pág. 1686); Navarro (Diario de Sesiones n. ${ }^{\circ}$ 105, 17 de octubre de 1820, pág. 1707) y Yandiola (ibídem, pág. 1717).

90 Para el profesor Tomás y Valiente, en la composición del Consejo de Estado, efectivamente, los constituyentes habrían dado acogida a características propias de una Cámara Alta. $C f r$. Francisco Tomás y Valiente, "El Consejo de Estado en la Constitución de 1812", en Constitución: escritos de introducción histórica, Marcial Pons, Madrid, 1996, págs. 104, 108 y 112. También ha recogido esta idea María Isabel Cabrera, "Algunas consideraciones en torno al Consejo de Estado en la Constitución de 1812", Revista de Estudios Políticos, núm. 93, 1996, págs. 235 y 237. El profesor Coronas considera que ya en 1812 se identificó al Consejo de Estado con una Cámara Alta, Cfr. Santos M. Coronas González, "Los orígenes del sistema bicameral en España", en Juan Cano Bueso (edit.), Materiales para el estudio de la Constitución de 1812, Tecnos, Madrid, 1986, págs. 203-204. Sin embargo, aquí sostengo que esta identificación no se produjo hasta 1820.

91 Ramón de Salas, Lecciones de Derecho Público Constitucional (1821), Tomo II, Parte II, Lección XXII, C.E.C., Madrid, 1982, págs. 248-249.

92 The Westminister Review, abril de 1824, pág. 290.

93 Edinburgh Review, vol. XXIII, núm. 46, septiembre 1814, pág. 362. 
Frente a aquellos que trataron de ocultar la Cámara Alta bajo el Consejo de Estado, otros, sin embargo, no tuvieron tantos escrúpulos a la hora de mostrar su preferencia por el Senado. Así lo hicieron los escritores liberales más conservadores, procedentes de las filas afrancesadas, así como uno de los principales vindicadores de Constant en nuestro país, Ramón de Salas. En efecto, los antiguos afrancesados Gómez Hermosilla y Alberto Lista plasmaron sus ideas favorables al bicameralismo en el periódico más sólido del Trienio, El Censor, en el que también colaboró muy activamente Sebastián de Miñano. Este diario profesó primero unas ideas muy próximas al liberalismo doctrinario y a las teorías de Constant y Tracy, para ir inclinándose hacia las posturas ultra-realistas a finales del Trienio. Aunque en ocasiones El Censor siguió la pauta del liberalismo moderado español, esto es, asimilar el Consejo de Estado con el Senado ${ }^{94}$, no ocultó tampoco su preferencia por construir una Cámara Alta que lograse un equilibrio constitucional y que actuase, según había descrito Destutt de Tracy, como poder conservador ${ }^{95}$.

Por su parte, la propuesta de Senado de Ramón de Salas suponía una combinación entre el pensamiento posrevolucionario francés - muy en especial por Constant, Destutt de Tracy, aunque también de liberales como Lanjuinais- y el modelo constitucional norteamericano. De hecho, el punto de partida de su teoría era la separación de poderes rígida que se diseñaba en este último modelo ${ }^{96}$. Presupuesta esta separación, era preciso contar con la presencia de un "poder conservador" (denominación adoptada de Destutt de Tracy) destinado a garantizar el equilibrio entre el Ejecutivo y la Cámara Baja. El diseño de esta Cámara se parece bastante al propuesto en el proyecto constitucional de 1819; incluso el nombre de "Senado conservador" no le desagradaba a Salas quien, no obstante, lo descartaba por el aciago recuerdo de Napoleón.

La Cámara Alta diseñada por Salas se distanciaba del modelo de la Carta francesa de 1814. A diferencia de ésta, no era una Cámara nobiliaria, algo lógico, puesto que Salas, según vimos, denostaba incluso el estamentalismo que rezumaba el Consejo de Estado de la Constitución de Cádiz. Según Salas, la Cámara Alta francesa, elegida por el Rey, se inclinaba a favor del Monarca y se convertía, así, en un enemigo de la libertad. Su propuesta era, a la inversa, acercar el Senado al pueblo, convirtiéndola en una Cámara de elección popular conforme a un sistema proporcional, aunque siendo sus miembros vitalicios.

Las funciones del Senado estaban extraídas tanto del sistema norteamericano y británico (enjuiciamiento en procedimiento de impeachment, nombramiento de autoridades), como del Senado napoleónico (conservación de la Constitución, verificación de poderes electorales, declaración de inconstitu-

94 Vid. El Censor, núm. 4, 26 de agosto de 1820, págs. 277-282.

95 El Censor, n. ${ }^{\circ}$ 1, 5 de agosto de 1820, pp. 46-49; El Censor, n. ${ }^{\circ} 3,19$ de agosto de 1820, p. 204; El Censor, n. ${ }^{\circ}$ 4, 26 de agosto de 1820, pp. 258-282; El Censor, n. ${ }^{\circ}$ 7, 16 de septiembre de 1820, pp. 48-50; El Censor, n. ${ }^{\circ}$ 9, 30 de septiembre de 1820, pp. 200-201; El Censor, n. ${ }^{\circ} 32,10$ de marzo de 1821, pp. 136-137; El Censor, n. ${ }^{\circ} 45$, 9 de junio de 1821, p. 183

96 Vid. Ramón Salas, Lecciones de Derecho Público constitucional para las escuelas de España (1821), Centro de Estudios Constitucionales, Madrid, 1982, págs. 11, 106, 107, 119. 
cionalidad de los actos del Ejecutivo y Legislativo, declaración de necesidad de reforma constitucional... $)^{97}$, esto es, de jury constitutionnel, según había propuesto Sieyès. Sin embargo, el Senado de Salas carecía de participación en el poder legislativo: ni iniciativa, ni deliberación, ni veto (en manos del Rey). Se trataba a todas luces de un nuevo poder estatal —el conservador- destinado a coordinar y salvaguardar la rígida división de poderes propuesta. Sus funciones muestran un ligamen directo con la Constitución, al salvaguardar el equilibrio que ésta diseñaba, y al garantizar su validez (reforma constitucional, anulación de actos inconstitucionales, exigencia de responsabilidad...). El Senado que diseñaba constituía, pues, una abstracción de los cometidos de "freno" característicos de las Cámaras Altas anglosajonas, hasta el punto de desprenderse de los cometidos legislativos para centrarse en aquellas facultades más intrínsecamente garantistas. Se diseñaba, así, un primer ensayo (muy primario, desde luego), de control de constitucionalidad, tal y como ya había previsto en su día Sieyès con el jury constitutionnel. Del Senado legislador se había pasado al Senado meramente conservador.

Pero las propuestas de Salas no tuvieron eco inmediato. No sólo fueron desoídas durante el Trienio, sino que tampoco hallaron plasmación normativa en 1834, cuando, restablecido el régimen representativo tras la ominosa década, el Estatuto Real implanta, por fin, un bicameralismo de corte británico, muy influido por la Constitución francesa de 1830 y la belga de 1831. En el Estatuto las propuestas moderadas, más que las de Salas, hallarán finalmente acomodo. La larga singladura de intentos bicamerales llegaba a su fin y se convertía en realidad.

ABSTRACT. The article pretends to show how the debate about the Senate was one of the first discussions of the Spanish constitutional history. In fact, the "Estatuto Real" (1834) was only the norm to formalize a debate that was really born in 1808. In the XVIIIth Century scholars just tried to summon a Spanish Parliament (Cortes) with no reference about its organization. But since 1808, it can be found some proposals to create a two-Chambers Parliament. The main "bicameral" model was the British, that showed a High Chamber to balance the Constitution; less important was the French model of the Constitution of 1795. The balance idea supposed a little confusion between the Senate and some traditional Spanish institutions that were created as an intermediate between the King and the Community (iudex medius). But when the Junta Central was summoned, proposals of a real legislative Senate begun to appear, and this model was also used in the "Trienio Liberal" (1820-1823), when some liberals tried to transform the "Consejo de Estado" into a sort of Senate. In fact, 
an important group of politicians tried to leave the constitutional model created in 1812; and, in 1819, and even since the "Trienio Liberal" (1820-1823) this group made clear proposals to create a "conservative Senate", such as Constant and Desttut de Tracy had described in France. This proposal would be the precedent of the "liberal-doctrinario" model that would be included in the "Estatuto Real". 